\title{
Electrodeposition of Nickel-Zinc Alloy from a Sulfamate Bath
}

\author{
Gabriella Roventi \\ Dept. of Materials, Environmental Sciences and Urban Planning, Polytechnic University of Marche, Ancona, Italy
}

\section{Email address:}

g.roventi@univpm.it

\section{To cite this article:}

Gabriella Roventi. Electrodeposition of Nickel-Zinc Alloy from a Sulfamate Bath. Advances in Materials. Special Issue: Software Advances in Electrodeposited Materials: Phase Formation, Structure and Properties. Vol. 4, No. 3-1, 2015, pp. 21-26. doi: 10.11648/j.am.s.2015040301.13

\begin{abstract}
The electrodeposition of Ni-Zn alloy coatings having high nickel content (74-97 wt\%) from a sulfamate bath was studied. The investigation was performed by means of cyclic voltammetry, potentiostatic electrodeposition, X-ray diffraction, scanning electron microscopy and energy dispersive X-ray analysis. The effect of the experimental parameters (deposition potential, zinc concentration, addition of sodiumdodecylsulphate) on the coating composition, morphology and structure was studied. The obtained results show that the addition of $\mathrm{Zn}^{2+}$ to the deposition bath leads to a strong decrease in the cathodic current density, indicating a remarkable inhibition of Ni reduction. Even if anomalous codeposition was observed for all the studied experimental conditions, nickel rich alloys were obtained due to the mass transport control. A sudden decrease in the current efficiency, indicating a decrease in the hydrogen overvoltage, was found on increasing zinc percentage in the alloy over than about $15 \mathrm{wt} \%$. The incorporation of $\mathrm{Zn}$ in the cfc Ni lattice up to about $20 \mathrm{wt} \%$ leads to a grain refinement and to an increase in hardness.
\end{abstract}

Keywords: Nickel, Zinc, Alloy, Electrodeposition, Sulfamate Bath

\section{Introduction}

Electrodeposition of nickel and nickel-zinc alloy coatings is of interest because these materials have an important role in many application fields such as the corrosion protection of steel [1-4] and the electrocatalysis [5]. For example, they are used as active layer on the electrodes for $\mathrm{H}_{2}$ production [6-8], for electrochemical decomposition of urea [9] or for methanol oxidation in alkaline medium [10].

The electrodeposition of $\mathrm{Ni}-\mathrm{Zn}$ alloy from aqueous solutions is classified as anomalous co-deposition, according to the Brenner definition [11] because the less noble metal deposits preferably on the cathode with respect the nobler one; therefore zinc-rich alloys are generally obtained. Many attempts have been made to explain the anomalous co-deposition of alloys, but there is still no universally accepted theory. At first, anomalous co-deposition was attributed to the $\mathrm{pH}$ increase at the cathode surface, which leads to zinc hydroxide precipitation and to the inhibition of the nobler metal discharge [12]. Swathirajan assumes that the anomalous codeposition is due to the underpotential deposition of zinc [13]. Other authors attribute the Ni-Zn anomalous co-deposition to the slow kinetics of nickel $[14,15]$.
Landolt demonstrated that anomalous codeposition of iron group metals involves both inhibiting and accelerating effects $[16,17]$. However, $\mathrm{Zn}-\mathrm{Ni}$ codeposition in aqueous solution is not always anomalous, as there are particular experimental conditions, which allow the electrodeposition of nickel-rich alloys [18]

In order to avoid the electrodeposition of alloys with high zinc content from aqueous solutions, some authors used low temperature molten salts $[9,20]$ or eutectic-based ionic liquid [21-23].

The electrodeposition of zinc-rich $\mathrm{Zn}-\mathrm{Ni}$ alloys from aqueous solutions has been widely studied, but only few works have been performed on nickel-rich alloys [15,24,25]. Chloride baths have been used in these researches. Previously, the electrodeposition of Ni-Zn alloy coatings with high nickel content from a Watts type bath was studied [26]; nickel rich alloys were obtained due to the mass transport control; the results showed that the alloys having $\mathrm{Zn}$ content higher than about $8 \mathrm{wt} \%$ are formed by $\alpha$ and $\beta$ phase.

The aim of this work was to study the electrodeposition of nickel-rich Ni-Zn alloy from a sulfamate bath. The investigation was performed by means of cyclic voltammetry and potentiostatic electrodeposition. The effect of the experimental parameters (deposition potential, zinc 
concentration, addition of sodiumdodecylsulphate) on the alloy composition, morphology and structure was studied.

\section{Experimental}

\subsection{Electrodeposition Bath}

$\mathrm{Ni}-\mathrm{Zn}$ alloy codeposition was studied by means of cyclic voltammetry and potentiostatic electrodeposition carried out at $50{ }^{\circ} \mathrm{C}$ in a sulfamate bath. The composition of the used bath was the following: $\mathrm{Ni}\left(\mathrm{SO}_{3} \mathrm{NH}_{2}\right)_{2} \cdot 4 \mathrm{H}_{2} \mathrm{O} \quad 400 \mathrm{~g} \mathrm{dm} \mathrm{dm}^{-3}$; $\mathrm{NiCl}_{2} \cdot 6 \mathrm{H}_{2} \mathrm{O} 20 \mathrm{~g} \mathrm{dm}^{-3} ; \mathrm{ZnSO}_{4} \cdot 7 \mathrm{H}_{2} \mathrm{O} 5,10 \mathrm{mM} ; \mathrm{H}_{3} \mathrm{BO}_{3} 40 \mathrm{~g}$ $\mathrm{dm}^{-3}$. Some tests were performed on adding $1 \mathrm{~g} \mathrm{dm}^{-3}$ sodiumdodecylsulphate (SDS) to the bath. All the solutions were prepared with doubly distilled water and analytical grade reagents.

\subsection{Cyclic Voltammetry}

Cyclic voltammetry was performed in a standard ASTM three-electrode cell, $1 \mathrm{dm}^{3}$ in capacity. The working electrode was a glassy carbon cylinder embedded in epoxy resin leaving an exposed area of $7.1 \mathrm{~mm}^{2}$; the counter-electrode was a platinum spiral and the reference was a $\mathrm{Ag} / \mathrm{AgCl}$ electrode (E $=0.208 \mathrm{~V}$ vs. SHE), mounted inside a Luggin capillary, whose tip was placed next to the working electrode surface. Before each experiment, the solution was deaerated with a $\mathrm{N}_{2}$ flux inside the cell. The potential was linearly swept from 0.500 to $-1.100 \mathrm{~V}$ vs $\mathrm{Ag} / \mathrm{AgCl}$ and then reversed to $0.500 \mathrm{~V}$. The scan rate was $20 \mathrm{mVs}^{-1}$.

\subsection{Potentiostatic Electrodeposition}

Potentiostatic electrodepositions were carried out in the potential range from -0.700 to $-1.100 \mathrm{mV}$ vs $\mathrm{Ag} / \mathrm{AgCl}$ by using a beaker $800 \mathrm{ml}$ in capacity as electrochemical cell. The working electrode was a mild steel disc mounted in a flat specimen holder with an exposed area of $314 \mathrm{~mm}^{2}$. Before each experiment, the disc was smoothed by emery paper (from 300 to 1000 grit) and degreased by anodic and cathodic electrolysis in a $60 \mathrm{~g} \mathrm{dm}^{-3} \mathrm{NaOH}$ at $4 \mathrm{~V}$ against graphite anodes; it was then neutralised in a $2 \mathrm{wt} \% \mathrm{HCl}$ solution and rinsed with distilled water. The disc was weighed before and after the electrodeposition to obtain the amount of the deposited alloy; the anode was a nickel sheet and the reference was an $\mathrm{Ag} / \mathrm{AgCl}$ electrode. The electrodeposition time was chosen in order to obtain coatings with a thickness ranging from 7 to $10 \mu \mathrm{m}$, except for the deposits to be submitted to microhardness measurements, for which deposition was prolonged until the thickness was $30 \mu \mathrm{m}$, in order to avoid the signal of the steel substrate. Both cyclic voltammetry and potentiostatic electrodeposition were performed at $50{ }^{\circ} \mathrm{C}$ by using an EG \& G Princeton Applied Research potentiostat/galvanostat Mod. 273 controlled by a personal computer.

$\mathrm{Ni}$ and $\mathrm{Zn}$ partial current densities $\left(i_{N i}\right.$ and $i_{Z n}$ ) were calculated from the weights of deposited nickel and zinc by means of Faraday's law. Hydrogen partial current density $\left(i_{H 2}\right)$ was calculated as the difference between total current density and $\left(i_{N i}+i_{Z n}\right)$; current efficiency $(\eta)$ was calculated as percentage of $\left(i_{N i}+i_{Z n}\right)$ with respect to the total current density.

\subsection{Coating Characterization}

Morphology and chemical composition of the coatings were studied by scanning electron microscopy (SEM) coupled with energy dispersive X-Ray analysis (EDX). A Zeiss Supra 40 microscope and a Bruker Quantax serie $5000 \mathrm{~L} \mathrm{~N}_{2}$-free XFlash device were used.

The alloy structure was analysed by means of X-ray diffraction analysis (XRD), by using a Philips PW 1730 diffractometer with $\mathrm{Cu} \mathrm{K} \alpha$ radiation $(\lambda=0.154 \mathrm{~nm})$. The crystallite size was determined by means of Scherrer equation [27].

Vickers microhardness of the deposits was determined by means of a HX-1000 Remet equipment, using a $25 \mathrm{~g}$ load, in order to obtain an indentation depth lower than $1 / 10$ of the deposit thickness.

\section{Results and Discussion}

\subsection{Cyclic Voltammetry}

Fig. 1 shows the cyclic voltammetry curves obtained on glassy carbon at $50{ }^{\circ} \mathrm{C}$ with different concentrations of $\mathrm{Zn}^{2+}$ in the bath; the cathodic potential sweep was reversed at $-1.100 \mathrm{~V}$. Nickel deposition from the bath without zinc (curve a) starts at about $-0.780 \mathrm{~V}$; the addition of $5 \mathrm{mM} \mathrm{Zn}^{2+}$ (curve b) does not influence significantly the onset of the deposition process, while the addition of $10 \mathrm{mM} \mathrm{Zn}^{2+}$ (curve c) shifts it to about -0.820 V. Fig. 1 shows that the addition of $\mathrm{Zn}^{2+}$ leads to a strong decrease in the cathodic current density, indicating an inhibition of $\mathrm{Ni}$ reduction, according to previous results obtained in a Watts type bath [26]. In all the curves in Fig. 1, the forward and the reverse scan form a relatively large loop, due to the fact that both pure $\mathrm{Ni}$ and $\mathrm{Ni}-\mathrm{Zn}$ alloy reduction current densities during the forward scan are lower than that during the reverse scan. This indicates that the electrodeposition on the freshly deposited nickel or $\mathrm{Ni}-\mathrm{Zn}$ alloy surface required less energy than that on glassy carbon.

On increasing $\mathrm{Zn}^{2+}$ concentration in the bath to $10 \mathrm{mM}$ (Fig. 1 , curve c), during the cathodic reverse scan, the current density forms a plateau in the potential range from -1.0 to $-0.88 \mathrm{~V}$. A cathodic plateau has been observed also for Ni-Zn electrodeposition in a chloride-acetic bath [15] and in a Watts type bath [26]. The cathodic plateau in the reverse cathodic scan has been associated previously to the contemporary deposition of $\alpha$-phase (solid solution of $\mathrm{Zn}$ in the fcc Ni lattice) and $\mathrm{Ni}-\mathrm{Zn} \beta$-phase [26]. The anodic curve of pure $\mathrm{Ni}$ deposition (Fig. 1, curve a) shows only one wide peak with the maximum at $0.020 \mathrm{~V}\left(\mathrm{a}_{1}\right)$. On adding $5 \mathrm{mM} \mathrm{Zn}^{2+}$ to the bath (curve $b$ ), the anodic curve shows a double oxidation peak, with the maxima a $-0.100\left(a_{1}\right)$ and $-0.190 \mathrm{~V}\left(a_{2}\right)$. The first maximum can be related to the $\alpha$-phase dissolution; this peak is shifted to more negative potentials with respect to that of pure $\mathrm{Ni}$, due to the presence of zinc as solid solution in the $\mathrm{Ni}$ lattice. The anodic peak $\mathrm{a}_{2}$ has been observed previously in a 
Watts type bath and has been attributed to the dissolution of zinc from $\beta$-phase [26]. Also the anodic curve obtained with $10 \mathrm{mM} \mathrm{Zn}^{2+}$ shows a double oxidation peak, with the maxima at $-0.160\left(a_{1}\right)$, shifted to a more negative potential with respect to that of curve $b$, due to the higher $\mathrm{Zn}$ content, and at $-0.190 \mathrm{~V}$ $\left(a_{2}\right)$.

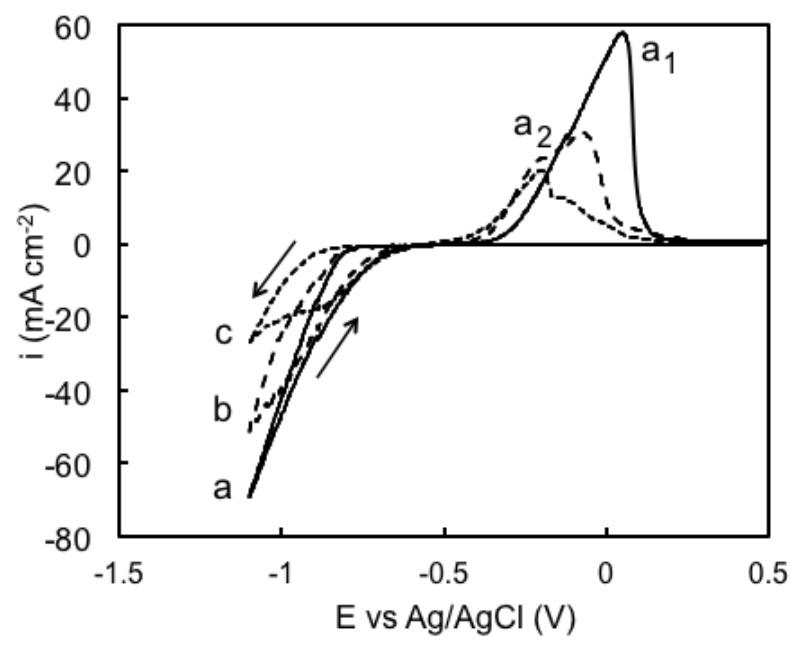

Figure 1. Cyclic voltammetry curves obtained on glassy carbon from the sulfamate bath with increasing concentrations of $\mathrm{Zn}^{2+}$ : a) $\mathrm{Zn}^{2+} 0 \mathrm{mM}$; b) $\mathrm{Zn}^{2+}$ $5 \mathrm{mM}$; c) $\mathrm{Zn}^{2+} 10 \mathrm{mM}$. $\mathrm{T}=50{ }^{\circ} \mathrm{C}$. Scan rate: $20 \mathrm{mV} \mathrm{s}^{-1}$.

\subsection{Potentiostatic Electrodepositions}

Figure 2 shows the effect of $\mathrm{Zn}^{2+}$ concentration in the bath on $\mathrm{Zn}$ percentage in the alloys $\left(\mathrm{Zn}_{\mathrm{d}}\right)$ obtained at different deposition potentials from the baths containing 5 and $10 \mathrm{mM}$ $\mathrm{Zn}^{2+}$, with and without sodiumdodecylsulphate (SDS). Zn percentage decreases on increasing cathodic polarization. This trend is similar to that obtained previously by using a Ni-rich bath [26], but opposite to that found by other authors for nickel rich alloy electrodeposition from $\mathrm{Zn}$-rich baths $[19,21,24]$. As found previously, by using a Watts type bath, the decrease in $\mathrm{Zn}$ percentage in the alloy with the increase in the cathodic polarization can be attributed to the mass transfer control, due to the low zinc ions concentration in the bath.

In fact, the partial current density of zinc (Fig. 3, curve c) reaches a limit value at $-1000 \mathrm{mV}$. On increasing $\mathrm{Zn}^{2+}$ concentration in the bath from 5 to $10 \mathrm{mM}$ (Fig. 2, curves a and $\mathrm{b}$ respectively) a significant increase in the $\mathrm{Zn}$ percentage in the alloy can be observed at the potentials more negative than $-0.800 \mathrm{~V}$, while at potentials more positive the difference is very low. The addition of SDS to the bath does not change significantly the zinc content of the alloy: at all the deposition potentials, only a slight increase in $\mathrm{Zn}$ percentage can be observed in Fig. 2.

All the $\mathrm{Zn}$ percentages in the deposits reported in Fig. 2 are higher than $\mathrm{Zn}$ percentage in the bath $(0.88 \%$ for the bath containing $10 \mathrm{mM} \mathrm{Zn}^{2+}$ ), indicating that $\mathrm{Zn}-\mathrm{Ni}$ codeposition is anomalous for all the studied experimental conditions. With respect to the Watts type bath studied previously [26], sulfamate bath seems to permit a better control of the $\mathrm{Zn}$ percentage in the coatings.

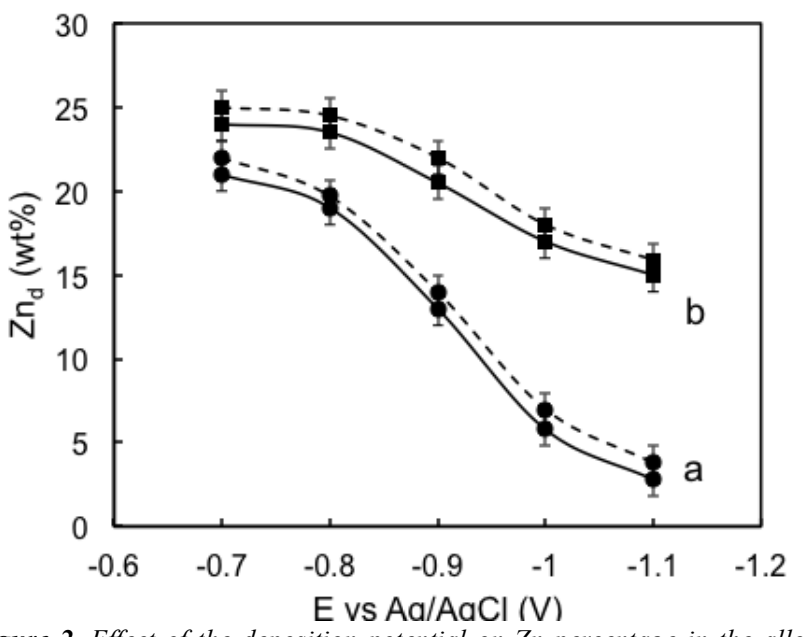

Figure 2. Effect of the deposition potential on $\mathrm{Zn}$ percentage in the alloys obtained from the sulfamate baths with (dashed line) and without SDS (solid line): a) $\mathrm{Zn}^{2+} 5 \mathrm{mM}$; b) $\mathrm{Zn}^{2+} 10 \mathrm{mM} . \mathrm{T}=50^{\circ} \mathrm{C}$.

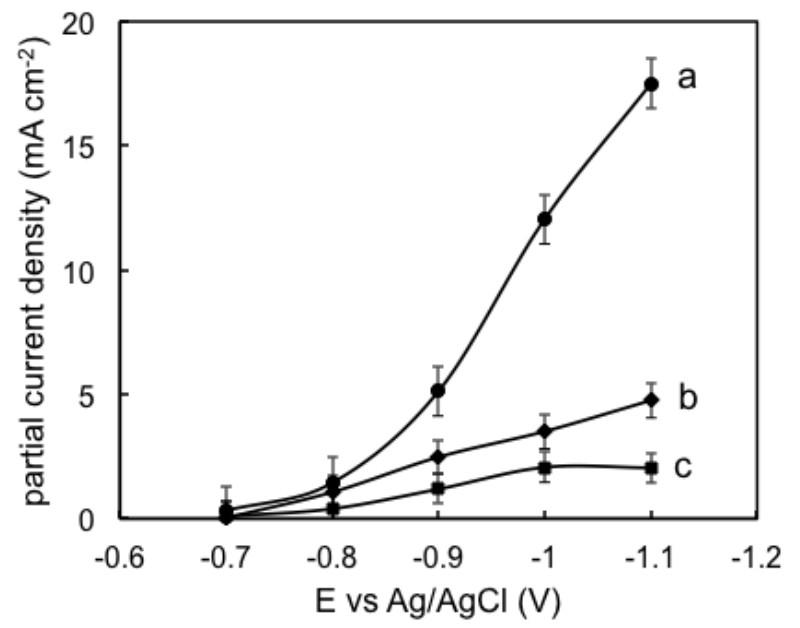

Figure 3. Partial current densities: a) $i_{N i}$; b) $i_{H 2}$; c) $i_{Z n} . Z n^{2+} 10 \mathrm{mM} . \mathrm{T}=50^{\circ} \mathrm{C}$.

The effect of $\mathrm{Zn}^{2+}$ concentration in the bath on the current efficiency at the different applied potentials is shown in Fig. 4. Current efficiencies obtained with the bath containing $5 \mathrm{mM}$ $\mathrm{Zn}^{2+}$ without SDS (curve a, solid line) are about $96 \%$ for potential values more negative than $-1.000 \mathrm{~V}$. A decrease down to $65 \%$ was observed on changing the potential from -1.000 to $-0.700 \mathrm{~V}$. On increasing $\mathrm{Zn}^{2+}$ concentration in the bath to $10 \mathrm{mM}$ (curve $\mathrm{b}$, solid line), the current efficiencies are around $80 \%$ for potential values more negative than $-1.000 \mathrm{~V}$ and decrease down to $55 \%$ on going from -1.000 to $-0.700 \mathrm{~V}$. Even in this bath, the addition of SDS (curve b, dashed lines) leads only to a slight decrease in the current efficiency. By comparing Fig. 2 and Fig. 4, it can be seen that Ni-Zn codeposition occurs with current efficiency higher than $80 \%$ only when $\mathrm{Zn}$ percentage in the deposit is lower than about 15 $w t \%$. The dependence of the current efficiency from the zinc content in the alloy has been found also by Balej et al. on performing $\mathrm{Ni}-\mathrm{Zn}$ electrodeposition from a simple chloride solution containing $\mathrm{H}_{3} \mathrm{BO}_{3}$ [25]. 


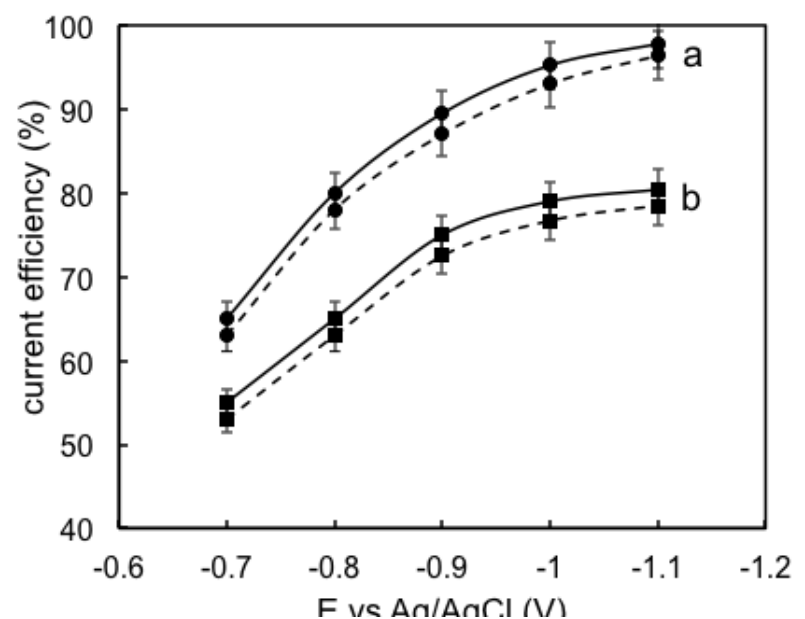

Figure 4. Effect of the deposition potential on the current efficiency for the $\mathrm{Ni}$-Zn alloy electrodeposition performed with the bath with (dashed line) and without SDS (solid line): a) $\mathrm{Zn}^{2+} 5 \mathrm{mM}$; b) $\mathrm{Zn}^{2+} 10 \mathrm{mM} . \mathrm{T}=50^{\circ} \mathrm{C}$.

Figure 5 shows SEM images of pure Ni and Ni-Zn alloys obtained at the different experimental conditions. The micrograph of pure Ni deposit revealed the typical shape of nickel crystallites (Fig. 5a). Ni-Zn alloy electrodeposited at $-1.000 \mathrm{~V}$ with $5 \mathrm{mM} \mathrm{Zn^{2+ }}$ (Fig. 5b, $\mathrm{Zn}_{\mathrm{d}} 7.1 \mathrm{wt} \%$ ) is also homogeneous and compact, but shows a strong decrease in the grain size. Ni-Zn alloy electrodeposited with the same bath at $-0.900 \mathrm{~V}\left(\mathrm{Zn}_{\mathrm{d}} 14.1 \mathrm{wt} \%\right)$ is cracked (Fig. 5c). The alloy obtained with the same bath at $-0.700 \mathrm{~V}\left(\mathrm{Zn}_{\mathrm{d}} 22.0 \mathrm{wt} \%\right)$ is not cracked and shows a globular morphology (Fig. 5d). This last alloy has a dark grey colour, while the others have a bright grey colour.

The XRD patterns obtained on pure $\mathrm{Ni}$ and on the alloys electrodeposited at different experimental conditions are shown in Fig. 6. Pure Ni pattern (curve a, intensity reduced 4 times) shows a strong orientation of the deposit and the reflection from the (200) planes is largely predominant. The alloy containing $7.1 \mathrm{wt} \% \mathrm{Zn}$ (curve b), exhibits all the peaks of $\alpha-\mathrm{NiZn}$ (substitutional solid solution of $\mathrm{Zn}$ in the $\mathrm{Ni}$ fcc lattice), with an increase in the reflections at the $2 \theta$ value characteristic for (111) planes. The deposit containing $14.1 \mathrm{wt} \%$ Zn (curve c), retains the fcc structure, but the peak assigned to the (200) planes decreases strongly and the peak assigned to the (111) planes becomes the main peak. The incorporation of $\mathrm{Zn}$ in the $\mathrm{Ni}$ lattice leads to a broadening of the peaks, indicating the decrease in grain size, together with a shifts towards lower $2 \theta$ values, due to the larger lattice parameter of $\alpha-\mathrm{NiZn}$, The present results agree with those of Gou et al. obtained for NiZn alloys having similar $\mathrm{Zn}$ content electrodeposited from low temperature molten salt [19]. The (220) reflection is shifted to even lower $2 \theta$ values by further increasing the zinc concentration to $22.0 \mathrm{wt} \%$ (curve $\mathrm{d}$ ); the shift is accompanied by a further decrease of the peak, but the broadening is reduced.
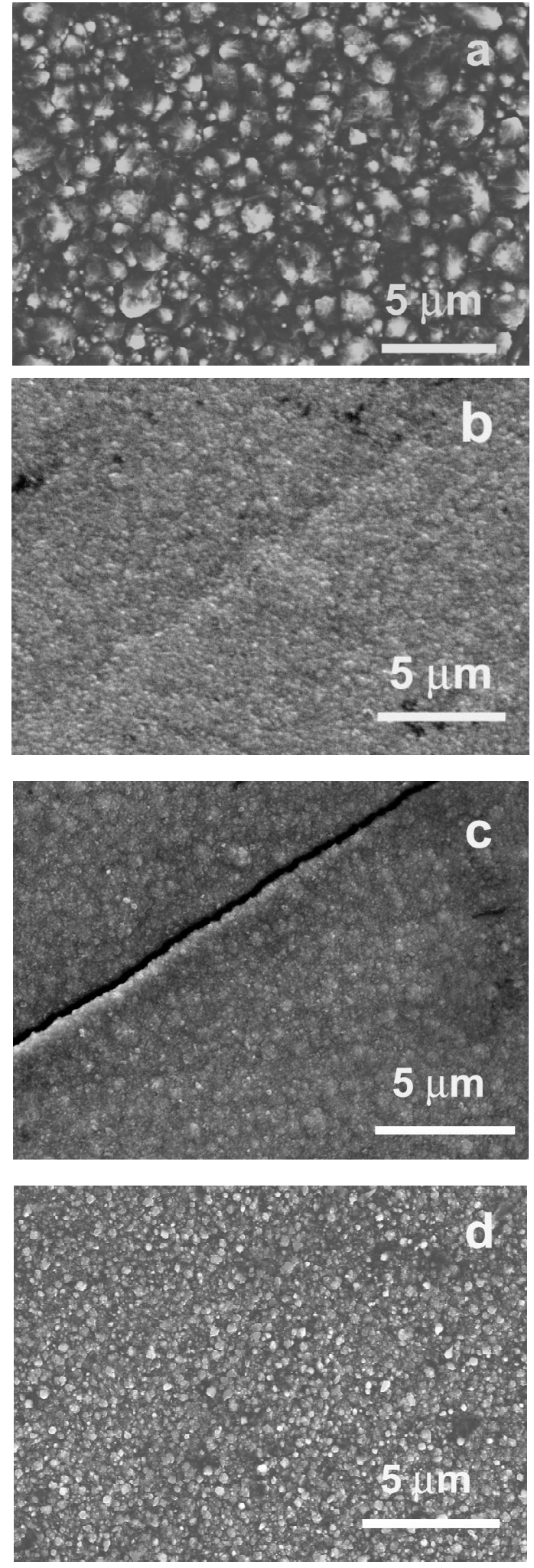

Figure 5. SEM image of: a) pure Ni deposit obtained at $-1.000 \mathrm{~V}$; b) Ni-Zn alloy obtained at $-1.000 \mathrm{~V}$ from the bath containing $5 \mathrm{mM} \mathrm{Zn^{2+ }}\left(\mathrm{Zn}_{d} 7.1 \mathrm{wt} \%\right)$; c) $\mathrm{Ni}-\mathrm{Zn}$ alloy obtained at $-0.900 \mathrm{~V}$ from the bath containing $5 \mathrm{mM} \mathrm{Zn^{2+ }}\left(\mathrm{Zn}_{d}\right.$ $14.1 \mathrm{wt} \%$ ); d) $\mathrm{Ni}$-Zn ally obtained at $-0.700 \mathrm{~V}$ from the bath containing $5 \mathrm{mM}$

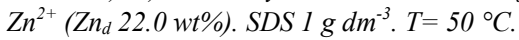




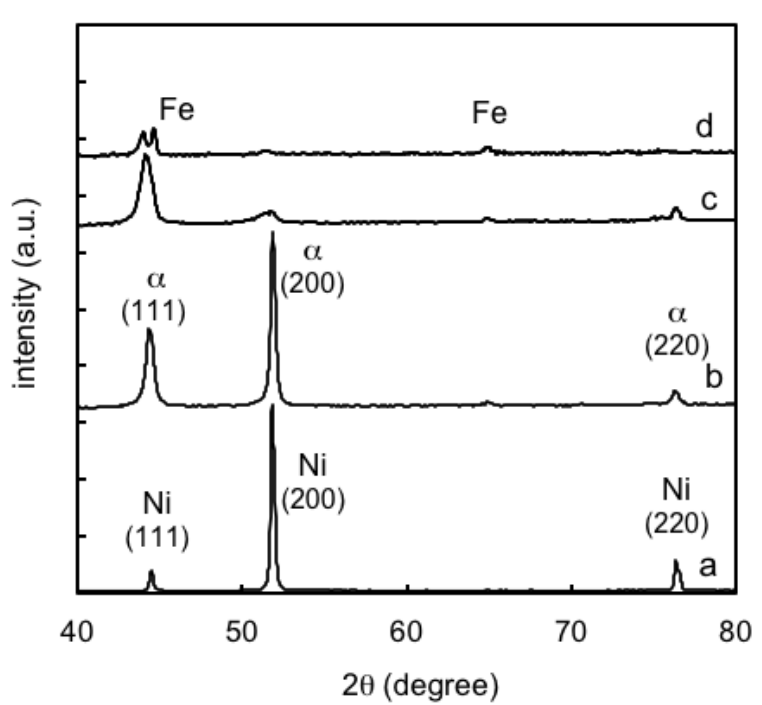

Figure 6. X-ray patterns of: a) pure Ni deposited at $-1.000 \mathrm{~V}$; b) Ni-Zn alloy obtained at $-1.000 \mathrm{~V}$ from the bath containing $5 \mathrm{mM} \mathrm{Zn^{2+ }}\left(\mathrm{Zn}_{d} 7.1 \mathrm{wt} \%\right)$; c) $\mathrm{Ni}$ - Zn alloy obtained at $-0.900 \mathrm{~V}$ from the bath containing $5 \mathrm{mM} \mathrm{Zn^{2+ }}\left(\mathrm{Zn}_{d}\right.$ $14.1 \mathrm{wt} \%)$; d) $\mathrm{Ni}$-Zn alloy obtained at $-0.700 \mathrm{~V}$ from the bath containing $5 \mathrm{mM}$

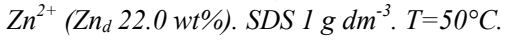

The effect of zinc percentage in the alloy on the grain size, calculated on the peak related to the reflections of the (111) planes by means of the Scherrer equation, is shown in Fig. 7. Even if the coatings were obtained at different experimental conditions, the grain size values have the same trend and depend primarily on the zinc content: the grain size of $\alpha$-phase decreases on increasing $\mathrm{Zn}$ percentage until about $20 \mathrm{wt} \%$, then it increases. These results can be explained on considering that for zinc percentages over $20 \%$, the increase in zinc content in the alloy occurs by the deposition of a zinc rich new phase. Previously was found in a Watts type bath the contemporary deposition of $\alpha$ phase and the almost amorphous Ni-Zn $\beta$-phase (equilibrium content $49.2 \mathrm{wt} \% \mathrm{Zn}$ ) [26]; this phase cannot be identified by X-ray diffraction because its grain size is too small.

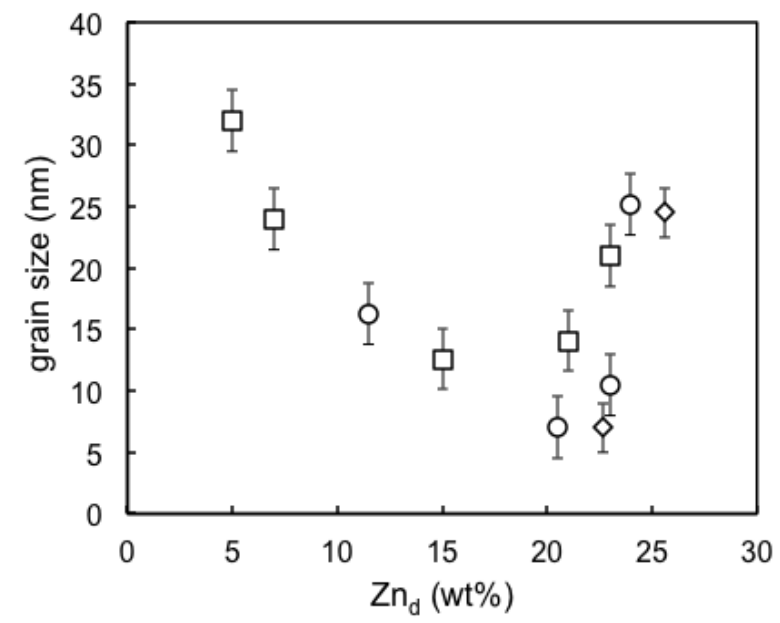

Figure 7. Effect of zinc percentage in the alloy on the grain size for Ni-Zn coatings obtained from different baths: $\square \mathrm{Zn}^{2+} 5 \mathrm{mM}$, SDS $1 \mathrm{~g} \mathrm{dm}^{-3} ; \bigcirc \mathrm{Zn}^{2+}$ $10 \mathrm{mM} ; \diamond \mathrm{Zn}^{2+} 10 \mathrm{mM}$, SDS $1 \mathrm{~g} \mathrm{dm}^{-3} . \mathrm{T}=50^{\circ} \mathrm{C}$.

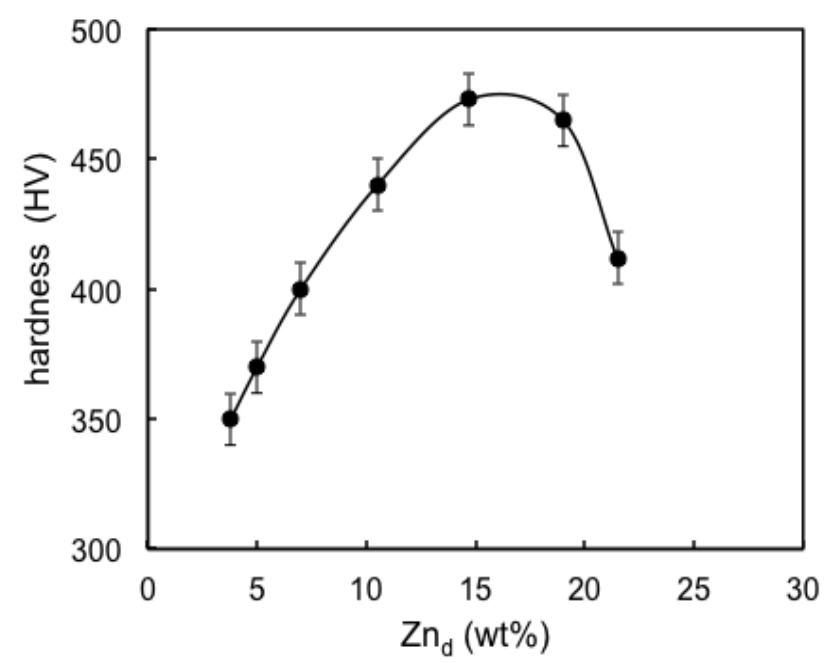

Figure 8. Effect of zinc percentage in the alloy on Ni-Zn coatings hardness. $\mathrm{Zn}^{2+} 5 \mathrm{mM}$, SDS $1 \mathrm{~g} \mathrm{dm}^{-3} . \mathrm{T}=50^{\circ} \mathrm{C}$.

The dark grey colour of the alloy containing $22.0 \mathrm{wt} \% \mathrm{Zn}$ confirms the hypothesis of the contemporary deposition of $\alpha$ and $\beta$-phase because this last phase has a dark brown colour [26].

Fig. 8 shows the significant influence of the alloy grain size on the microhardness of the coatings: lower is the grain size higher is the hardness.

\section{Conclusions}

The electrodeposition of Ni-Zn alloys having high nickel content (74-97 wt\%) from a sulphamate bath was studied. From the obtained results, the following conclusions can be drawn:

1) The addition of $\mathrm{Zn}^{2+}$ to the deposition bath leads to a strong decrease in the cathodic current density indicating a remarkable inhibition of Ni reduction.

2) On increasing zinc percentage in the alloy over than about $15 \mathrm{wt} \%$, current efficiency quickly decreases.

3) For all the studied experimental conditions, the $\mathrm{Ni}$ and $\mathrm{Zn}$ co-deposition is anomalous.

4) The incorporation of $\mathrm{Zn}$ up to about $20 \mathrm{wt} \%$ in the $\mathrm{cfc} \mathrm{Ni}$ lattice leads to a grain refinement and to an increase in hardness. When the alloy $\mathrm{Zn}$ percentage is higher than about $20 \mathrm{wt} \%$, the $\alpha \mathrm{Ni}$ grain size increases and the hardness decreases.

5) With respect to the results obtained from a Watts type bath, sulfamate solution permits a better control of the NiZn alloy composition and produces more homogeneous coatings.

\section{References}

[1] D. Crotty, Zinc alloy plating for the automotive industry. Met. Finish. 94 (1996) 54-58.

[2] F.J. Fabri Miranda, O.E. Barcia, O.R. Mattos, R. Wiart, Electrodeposition of $\mathrm{Zn}-\mathrm{Ni}$ alloys in sulfate electrolytes. I. Experimental approach. J. Electrochem. Soc. 144 (1997) 3441-3448. 
[3] S. Chouchane, A. Levesque, J. Douglade, R. Rehamnia, J.P. Chopart, Microstructural analysis of low Ni content $\mathrm{Zn}$ alloy electrodeposited under applied magnetic field. Surf. Coat. Technol. 201 (2007) 6212-6216.

[4] M.M. Abou-Krisha, Electrochemical study of zinc-nickel codeposition in sulphate bath. Appl. Surf. Sci. 252 (2005) 1035-1048.

[5] J. Ebothé, M. Hiane, Coating and active surface of Ni-Zn alloys studied by atomic force microscopy. Appl. Surf. Sci. 183 (2001) 93-102.

[6] M.J. De Giz, J.C.P. Silva, M. Ferreira, S.A.S. Machado, E.A. Ticianelli, L.A. Avaca, E.R. Gonzalez, Progress on the development of activated cathodes for water electrolysis. Int. J. of Hydrogen Energy. 17 (1992) 725-729.

[7] L. Chen, A. Lasia, Influence of the adsorption of organic compounds on the kinetics of the hydrogen evolution reaction on Ni and Ni-Zn alloy electrodes. J. Electrochem. Soc. 139 (1992) 1058-1064.

[8] I. Herraiz-Cardona, E. Ortega, V. Pérez-Herranz, Impedance study of hydrogen evolution on $\mathrm{Ni} / \mathrm{Zn}$ and $\mathrm{Ni}-\mathrm{Co} / \mathrm{Zn}$ stainless steel based electrodeposits. Electrochim. Acta 56 (2011) 1308-1315.

[9] W. Yan, D. Wang, G.G. Botte, Electrochemical decomposition of urea with Ni-based catalysts. Appl.Catalysis B: Environmental 127 (2012) 221-226.

[10] E. Altunbas Sahin, G. Kardas, Cobalt-modified nickel-zinc catalyst for electrooxidation of methanol in alkaline medium. J. Solid State Electrochem. 17 (2013) 2871-2877.

[11] A. Brenner Electrodeposition of Alloys, Vol I and II, Academic Press, New York and London, 1963.

[12] D.E. Hall, Electrodeposited zinc-nickel alloy coatings - a review. Plat. Surf. Finish. 71 (1983) 59-65.

[13] S. Swathirajan, Electrodeposition of zinc + nickel alloy phases and electrochemical stripping studies of the anomalous codeposition of zinc. J. Electroanal. Chem. 221 (1987) 211-228.

[14] L. Felloni, R. Fratesi, E. Quadrini, G. Roventi, Electrodeposition of zinc-nickel alloys from chloride solution. J. Appl. Electrochem. 17 (1987) 574-582.

[15] Y.P. Lin, J.R. Selman, Electrodeposition of corrosion-resistant Ni-Zn alloy. I. Cyclic voltammetric study. J. Electrochem. Soc. 140 (1993) 1299-1303.
[16] N. Zech, E. Podlaha, D. Landolt, Anomalous codeposition of iron group metals I. Experimental results. J. Electrochem. Soc. 146 (1990) 2886-2891.

[17] D. Landolt, Enhancement and inhibition of partial reactions in alloy deposition. Proc.-Electrochem. Soc. PV 2004-23 (2006) 159-171.

[18] G. Roventi, R. Fratesi, R.A. Della Guardia, G. Barucca, Normal and anomalous codeposition of $\mathrm{Zn}-\mathrm{Ni}$ alloys from chloride bath. J. Appl. Electrochem. 30 (2000) 173-179.

[19] S.P. Gou, I.W. Sun, Electrodeposition behaviour of nickel and nickel-zinc alloys from the zinc chloride-1-ethyl-methylimidazolium chloride low temperature molten salt. Electrochim. Acta 53 (2008) 2538-2544.

[20] N. Koura, Y. Suzuki, Y. Idemoto, T. Kato, F. Matsumoto, Electrodeposition of $\mathrm{Zn}-\mathrm{Ni}$ alloy from $\mathrm{ZnCl}_{2}-\mathrm{NiCl}_{2}$-EMIC and $\mathrm{ZnCl}_{2}-\mathrm{NiCl}_{2}$-EMIC-EtOH ambient-temperature molten salts. Surf. Coat. Technol. 169-170 (2003) 120-123.

[21] H.Y. Yang, X.W. Guo, X.B. Chen, S.H. Wang, G.H. Wu, W.J. Ding, N. Birbilis, On the electrodeposition of nickel-zinc alloys from a eutectic-based ionic liquid. Electrochim. Acta 63 (2012) 131-138.

[22] S. Fashu, C.D. Gu, X.L. Wang, J.P. Tu, Influence of electrodeposition conditions on the microstructure and corrosion resistance of $\mathrm{Zn}-\mathrm{Ni}$ alloy coatings from a deep eutectic solvent. Surf. Coat. Technol. 242 (2014) 34-41.

[23] S. Fashu, C.D. Gu, X.L. Wang, J.P. Tu, Structure, composition and corrosion resistance of $\mathrm{Zn}-\mathrm{Ni}-\mathrm{P}$ alloys electrodeposited from a ionic liquid based on choline chloride. J. Electrochem. Soc. 161 (2014) D3011-D3017.

[24] Y.P. Lin, J.R. Selman, Electrodeposition of Ni-Zn alloy. II Electrocrystallization of Zn, Ni and Ni-Zn alloy. J. Electrochem. Soc. 140 (1993) 1304-1311.

[25] J. Balej, J. Divisek, H. Schmitz, J. Mergel, Preparation and properties of Raney nickel electrodes on Ni-Zn base for $\mathrm{H}_{2}$ and $\mathrm{O}_{2}$ evolution from alkaline solutions. Part I: electrodeposition of Ni-Zn alloys from chloride solutions. J. Applied Electrochem. 22 (1992) 705-710.

[26] G. Roventi, R. Cecchini, A. Fabrizi, T. Bellezze, Electrodeposition of nickel-zinc coatings with high nickel content, In press.

[27] P. Scherrer, Bestimmung der Grösse und der inneren Struktur von Kolloidteilchen mittels Röntgenstrahlen, Nachr. Ges. Wiss. Göttingen 26 (1918) pp 98-100. 